\title{
A nép nélküli néppártok \\ A német néppártok politikai státuszának változása 1990-2021 között
}

\author{
Catch-All Parties Without Electorate
}

Changes in the Political Status of the German Catch-All Parties Between 1990-2021

Molnár Tamás Levente és Tóth Beáta

https://doi.org/10.47707/Kulugyi Szemle.2021.4.2

Összefoglaló: Németországban az 1949 óta eltelt időszak két meghatározó néppártja, a CDU/CSU és az SPD a német újraegyesítés óta eltelt több mint 30 évben fokozatosan veszitett a politikai befolyásából. E jelenség mögött számos tényező áll: szociológiai szempontból a társadalom fokozódó individualizálódása, mely a társadalmilag önszerveződő csoportokban való egyre passzívabb részvételben ölt testet; a politikai folyamatok professzionalizálódása, ami a politikai elitek és a társadalom közötti elidegenedéshez vezet; valamint a német társadalon diverzebbé válása, ami az állampolgároknak a politika iránti jelentősen eltérő elvárásainak artikulálásában fejeződik ki. Politikai szempontból a néppártok szerepének csökkenése mögött álló leglényegesebb té nyezőt azok a döntések jelentik, amelyeket a néppártok a kormányzásuk idején hoztak, de jelentősen kikezdték az adott párt identitásmagjának egy bizonyos részét. Ennek hatására a néppártok már nem tudták lefedni a teljes politikai spektrumot, s ennek következményeként új pártok jelentek meg. A német politika az utóbbi bő három évtizedben jelentős mértékben „hollandizálódott”; korábban nem látott koalíciós formák léteznek az országban, a CDU/CSU és az SPD politikai súlya erodálódott, ugyanakkor a mai napig meghatározó ré szét képezik a német pártrendszernek.

Kulcsszavak: Németország, néppárt, pártrendszer, CDU/CSU, SPD

Abstract: The ho catch-all parties in Germany, which have dominated the politics of the country since 1949, have gradually lost a part of their political influence in the period after the reunification. Several factors are behind the 


\section{Külïgyi Szemle}

decline of the CDU/CSU and the SPD. From a sociological point of view, this includes the increasing level of individualization of the society, embodied in the decreased parlicipation of self-organized groups, the professionalization of political processes leading to an alienation between the political elites and the society, and the diversification of German sociely, which is expressed in the arliculation of ever different expectations from the sociely towards politics. From a political point of view, the most important factor behind the decline in the influence of catch-all parties is their various political decisions while on government, which challenged a cerlain part of these parlies' core identity. As a result, the calch-all parties were no longer able to cover the full political spectrum, which led to the emergence of new parties. A "Hollandization" of the German politics characterized the country's political system in the last 30 years; formerly unprecedented forms of coalition govern the country, leading to an erosion of the political weight of CDU/CSU and SPD, yet the two calch-all parties are still dominating the German party system.

Keywords: Germany, calch-all party, party system, CDU/CSU, SPD

\section{Bevezetés}

A német néppártok jövőjének kérdése legalább bő egy évtize de aktívan foglalkoztatja az ország közvéleményét. A II. világhá ború utáni németországi parlamentáris demokrácia két nagy nép pártja (Kereszténydemokrata Unió/Bajor Keresztényszociális Unió [Christlich Demokratische Union Deutschlands/Christlich-Soziale Union in Bayern, CDU/CSU], Németország Szociáldemokrata Pártja [Sozialdemokratische Parlei Deutschlands, SPD]) az ország 1990-es újraegyesítése óta fokozatosan veszít a politikai befolyásából. Ennek egyik igen fontos mutatója a két pártnak a küiönböző szövetségi, illet ve tartományi választásokon elért eredménye. A néppártok befolyá sának csökkenéséről számos publikáció jelent meg az elmúlt tíz évben - mind a különböző sajtótermékekben (ld. Seitz, 2008; Carstens, 2011; Doemens, 2014; Käppner, 2019), mind a tudományos élet képviselői részéről. Az utóbbiak írásai alapvetően három kategóriára oszt hatók. Az egyiknek a képviselői szerint a CDU/CSU és az SPD szerepe már az 1980-as évektől csökken, és igazából ma már - különféle 
okokból - képtelenek ellátni a klasszikus néppárti funkciójukat, ezért a továbbiakban nem lehet néppártként tekinteni őket (Lösche, 2009). A másik nézet szerint a támogatottságuk jelentősen csökkent ugyan, viszont még mindig elengedhetetlen pilléreit képezik a demokratikus pártrendszernek, így legfeljebb a néppártok eróziójáról beszélhetüink (Niedermayer, 2010). A harmadik álláspont, hogy azok a pártok, amelyeket ma néppártoknak nevezüink, javarészt már hosszú ideje nem számítanak igazán azoknak, mert esetükben különböző módszertani feltételek régóta nem teljesülnek; a néppárt valójában egy mítosz, ami igazából soha nem létezett, így megszűnni sem tud (Giebler, Lacewell, Regel és Werner, 2013).

A tanulmány ennek az alapvetően német tudományos vitának a fejlődéséhez kíván magyar nyelven hozzájárulni. Azt vizsgáljuk, hogy a két német néppárt az 1990 és 2021 között eltelt 31 évben milyen szer kezeti átalakulásokon ment keresztuil, hogyan alakult a támogatottságuk, és e folyamatnak a felszínen is látszódó aktuálpolitikai vetületein túl milyen mélyebb, strukturális okai vannak. A tanulmány fó kutatási kérdése, hogy a CDU/CSU-t és az SPD-t az utóbbi három évtizedben zajlott változások ellenére is néppártoknak lehet-e még nevezni.

A tanulmány során elsőként a „néppárt” fogalom jelentéstartal mát fogjuk meghatározni, bemutatva a témához kapcsolódó leglényegesebb tudományos eredményeket. Ezt a CDU/CSU és az SPD 1990 és 2021 közötti helyzetének a bemutatása, majd annak a feltárása követi, hogy mely politikai, szociológiai és kulturális változások miatt hagyja el a nép a néppártokat. Ezután nyugat-európai példák elemzésén keresztuil helyezzük keretbe a németországi folyamatokat, és a néppártok jövőjére vonatkozó kitekintéssel zárjuk a tanulmányt. A felhasznált források alapvetően két kategóriába sorolhatók: egyrészt a másodlagos - alapvetően német nyelvű - tudományos szakirodalomra, másrészt számos, a választási eredményeket, a párttagok vagy a küiönbözó társadalmi szervezetekben aktív tagok számának az alakulását mutató statisztikai kimutatásra. 


\section{Külïgyi Szemle}

\section{A néppárt konceptualizálása}

Ahhoz, hogy jobban megértsük, milyen folyamatok zajlottak a CDU/ CSU-n és az SPD-n mint néppárton belül az utóbbi harminc évben, először is szüikséges tisztázni, mit értünk „néppárt” alatt. A tanulmány tartalmi korlátai miatt nincs lehetőség a fogalom fejlődésének a részletes bemutatására, így csak a leglényegesebb tudományos eredményekre fogunk koncentrálni.

A fogalom konceptualizálása kapcsán fontos említést tennünk Otto Kirchheimer munkásságáról, aki komoly hatással volt az 1945 utáni politikatudományra, azon belül is különösen a pártrendszerek fejlődésének területére. Kirchheimer az 1965-ben megjelent tanulmányában a nyugat-európai pártrendszerek elemzésekor azt a megállapítást tette, hogy a II. világháború előtti időszakra jellemző tömegpárt, amely alapvetően jól meghatározható társadalmi osztályok és felekezeti hovatartozások mentén szerveződött, 1945 után elveszítette a jelentőségét, helyére pedig az úgynevezett gyưjiőpárt (catch-all party $^{1}$ vagy Allerweltspartei) lépett. ${ }^{2}$ Az új pártot leginkább az különbözteti meg a korábbi tömegpárttól, hogy „lemond a tömegek szellemi és morális integrálásáról, a figyelme középpontjába a választók kerüilnek hangsúlyosabban; a nagyobb ideológiai hatást feláldozza a további terjeszkedés és a gyors választási siker érdekében” (Kirchheimer, 1965, 27. o.). A kirchheimeri definíció szerint tehát egy politikai formáció a gyứjtő- vagy néppártosodás folyamata során megválik az ideológiai magját képező nehezék egy részétől, hogy a választási eredmény maximalizálása érdekében újabb és újabb társadalmi csoportok számára tudjon vonzó opciót nyújtani.

1 Kirchheimer a modern német politikatudomány egyik meghatározó alakjának számít ugyan, de a műveit amerikai emigrációban, angolul írta.

2 Kirchheimer tanulmányában nem alkalmazza a néppárt (Volkspartei) megnevezést, helyette a gyưjiőpárt (Allerweltspartei) fogalmat használja. Alf Mintzel politológus egy 1984-ben megjelent könyvében amellett érvel, hogy a néppárt kifejezést teljes mértékben vegyék ki a társadalomtudományi szakzsargonból, mivel a kifejezés a nemzetiszocialista múltra való tekintettel terhes és félreértésre adhat okot (Mintzel 1984, 323). Később nézeteit revideálva a néppártot a „nagypárt” szinonimájaként használja (Mintzel 1989, 14). 
A gyűjtőpárt terjeszkedése kapcsán ugyanakkor fontos követelmény, hogy olyan társadalmi csoportokat próbáljon egyszerre megszólítani, amelyek érdekei nem ütköznek lényegesen egymással, így az érintettek közötti különbségek áthidalhatók maradnak. A gyưjiőónárt legfontosabb funkciója „a jelöltek kiválasztása, akiknek a hivatali megválasztását a nyilvánosság legitimálja” (Kirchheimer, 1965, 39. o.). Az ilyen típusú pártot a karizmatikus és kompetensnek tűnő pártvezetés jellemzi, amelynek a konkrét politikai tartalmaknak a különböző társadalmi csoportok számára történő közvetítésén túl bizalmat is kell generálnia. Kirchheimer szerint a gyưjtőpárt kialakulásában elsődleges szerepet játszott a hidegháború során elért gazdasági fejlődés, amelynek hatására a korábbi - a klasszikus társadalmi osztályok érdekképviseletén alapuló - politikai szembenállás jelentősen veszített a relevanciájából, mivel az újonnan kialakult középosztály érdekképviselete másfajta politikai logikát követelt meg: ,amint a társadalom egy bizonyos képzettségi és jóléti szintet elér, úgy a szellemi és az anyagi igényeket specializálódott termelők fogják kielégíteni, függetlenül attól, hogy véleményképzésről vagy gazdasági termékek előállításáról van-e szó" (Kirchheimer, 1965, 39. o.).

Fontos ugyanakkor leszögezni, hogy Kirchheimer több okból is kritikus volt az új gyújtőpárttal szemben. Az ugyanis szerinte az állampolgárok számára egy tỏlüik viszonylag távol álló, nehezen megfogható, félhivatalos és idegen szervezet, amely valójában nem akarja a választókat a politikai folyamatokba integrálni, hanem - politikai fogyasztóknak tekintve őket - a küilönböző igényeiket a politikai termékeivel igyekszik kielégíteni. Ezzel szemben a II. világháború előtti tömegpárt sokkal közelebb állt a polgárokhoz: valóban arra törekedett, hogy a polgárok ügyeit előbbre vigye, továbbá védelmet és jövővíziót kínáljon nekik. Kirchheimer szerint ugyanakkor a tömegpárt bukása a választópolgári igények és a háború utáni politikai változás következtében szüikséges „civilizációs égéstermék” volt, de ez nem zárja ki, hogy a gyújtőpárt is valamikor hasonló sorsa jut - ez az opció a választói akarattól füigg. 


\section{Külïgyi Szemle}

Miután Kirchheimer megalkotta a néppártra vonatkozó definíci óját, amelyet alapvetően az 1950-es és 1960-as évekbeli CDU/CSU ra és az SPD-re alapozott, számos új konceptualizációs kísérlet tör tént a politikatudományban, ám azok „inkább a heurisztikán, mint sem világos definíciókon alapultak" (Mainwaring és McGraw, 2018, 1. o.). A néppárt meghatározásaként - elasztikus jellegének köszönhe tôen - az angolszász tudományos szaknyelvben számos konkuráló ki fejezés jelent meg: ilyen például az electoral-professional party, a vote seeking party vagy a brokerage party (ld. Panebianco, 1988; Wolinetz 2002; Krouwel 2006). Ugyanakkor a néppártkoncepció ellenállóságát bizonyítja, hogy a definíció a mai napig sem veszett ki sem az angolszász, sem a német tudományos szaknyelvből, és a fogalom a mai napig használatban van.

Egy másik, időben közelebb álló konceptualizálási kísérletet a politikatudós Peter Lösche jegyez. A szerző a vonatkozó tanulmányában a néppártnak négy indikátorát nevezi meg (Lösche, 2009):

1. Egy polgárok által alkotott politikai szervezet, amelynek tagjai, aktivistái és választói nem csupán egy társadalmi réteget, osztályt vagy hasonlót (pl. felekezeti hovatartozást) ölelnek fel, hanem alapvetően több ilyet foglal magában, ennélfogva tár sadalmilag heterogénnak tekinthető. A szavazói összetétele ugyanakkor nem vész el a kontúrnélküliségben, mert egy bizonyos társadalmi profil így is felfedezhetỏ, így a néppártot egy osztályalapú tömegpártként lehet meghatározni.

2. Modern kommunikációs módszerekkel minél szélesebb választói csoportokat igyekszik megszólítani és megnyerni. Ebben a saját törzsválasztói rétegéhez viszonylag közel álló társadalmi csoportok esetén tud a legeredményesebb lenni. Egy néppártnak a szavazatok 35 százalékát kell tartósan megszereznie a választásokon.

3. Csak a képviseleti demokráciákra alapuló parlamentáris vagy prezidenciális politikai rendszerekben képzelhető el. Ez azért lényeges kikötés, mert a néppártnak a hatalomra kerülés érdekében képesnek kell lennie a más pártokkal történő koalíciókötésre, 
tehát nem vindikálhatja magának az abszolút uralmi vagy az egyedüli akaratérvényesítési jogot.

4. Tagjainak egy része, kiváltképp a funkcionáriusai, a pártaktivis tái, de a választói közül is sokan szellemi, ideológiai és értékítéleti szempontból kötődnek a párthoz. A hozzá szorosabban kötődô csoport - a miliőbázis - egy lojálisabb magot jelent a néppárt számára, akikben megbízhat; ők a szavazók 20-25 százalékát teszik ki.

Lösche meghatározásának első és második pontja lényegében a kirchheimeri modell megismétlése, a pártkötődést hangsúlyozó negyedik pont ugyanakkor szembemegy annak állításaival. A pártkötő dés ugyanis Kirchheimer szerint éppen az az elem, amelyet a párt a néppártosodási folyamatban lényegében feláldoz a nagyobb választási siker elérése érdekében. Lösche viszont egy kompromisszumos megoldást dolgozott ki: a néppártnak van egy ún. ideológiai keménymagja, amelyen belül magas a pártkötődés foka, és az mögött áll a párthoz lazábban kötődő választói réteg. Az utolsó két pontban említett, válasz tói támogatottsági feltételnek nevezett százalékpontok ugyanakkor rendkívül önkényesnek tűnnek: a tanulmányban Lösche nem fejtette ki, hogy miért éppen ezekhez az arányokhoz köti a néppártiságot. Nem véletlen, hogy más szerzők (pl. Giebler et al., 2013) az eltérô vá lasztási rendszerekre való tekintettel máshogy határozzák meg ezt: a támogatásnak az összes többi pártra leadott szavazatoknak legalább a negyedét kell elérnie, amely így egy relatív szavazati arányt helyez elôtérbe. Ebből a tanulmányunk szempontjából az a lényeges, hogy a politikatudományban nincs egységes meghatározása annak, hogy a néppártnak mekkora választói támogatással kell rendelkeznie: a szer zők - az eltérő módszertanok alapján - 25 és 35 százalék között szokták meghúzni a határt.

Összegezve kijelenthető, hogy a néppárt a partikuláris érdekeket képviselő párttal szemben olyan gyújtőpárt, amely - alapvetően - a vá lasztási eredmény maximalizálása érdekében a lehető legszélesebb társadalmi csoportok megszólítására és mobilizálására törekszik. 


\section{Külïgyi Szemle}

Ehhez nem ideológiai, hanem pragmatikus és rugalmas politikai ál láspontokat képvisel, amelyek célja, hogy a politikai üzeneteit minél több választó felé tudja közvetíteni. A néppártot professzionális, funkcionális és hierarchikus pártstruktúra jellemzi, amelynek a fö törekvése, hogy a saját embereit közhivatalokhoz juttassa.

\section{A német néppártok helyzetének alakulása, 1990-2021}

\section{A választói támogatás alakulása szövelségi és tartományi szinteken}

Az egyik jelentős tényező, amellyel jól mérhető a két néppárt státuszának megváltozása az 1990 óta eltelt időszakban, a CDU/CSU és az SPD szövetségi és tartományi választásokon elért eredménye. A választói támogatásuk tekintetében az egyes választási időszakokban ciklikusság, illetve a tartományok vonatkozásában regionális különbségek figyelhetők meg, de összességében mind szövetségi, mind tartományi szinten megállapítható a támogatottságuk csökkenése. E trend ellenére azonban mindkét néppárt szavazóinak aránya továbbra is meghaladja a szakirodalomban a néppárt kritériumaként szokásosan bevett, tartósan legalább 25-35 százalékos eredményt.

Szövetségi szinten 1990-ben a CDU/CSU volt a legerósebb párt, 1998-ban azonban az SPD megelőzte az uniópártokat. Az arányok a következő két választáson is hasonlóképpen alakultak: 2002-ben mindkét párt azonos eredményt ért el, 2005-ben pedig ismét a CDU/ CSU vette át a vezetést, de az SPD lemaradása elenyésző volt. E tendenciában a 2009-es választás hozott jelentősebb fordulatot, amelyen az uniópártok több mint 10 százalékkal jobb eredményt értek el, mint a szociáldemokraták. A változásban az is szerepet játszott, hogy a választási részvétel 1990 óta a legalacsonyabb arányra, 70,8 százalékra esett vissza. 2013-ban a két párt eredményei közötti különbség tovább nőtt a CDU/CSU javára, 2017-ben pedig az SPD történetének legroszszabb eredményét érte el (ld. 1. ábra). A 2021-es szövetségi parlamenti választáson a néppártok támogatottsága történelmi mélypontot ért el: bár az SPD szavazóinak aránya az előző választáshoz képest növekedett, 
a CDU/CSU mindenidők leggyengébb eredményét produkálta. A két néppárt együttes támogatottsága nem érte el az 50 százalékot. Ez a mutató 1990-ben még 77,3 százalék volt, ám azóta folyamatosan ciklikusan csökkenő tendenciát mutat (Wahlrecht, 2021a).

\section{1. ábra ${ }^{3}$}

A CDU/CSU és az SPD szövetségi választási eredményei 1990-2021 között

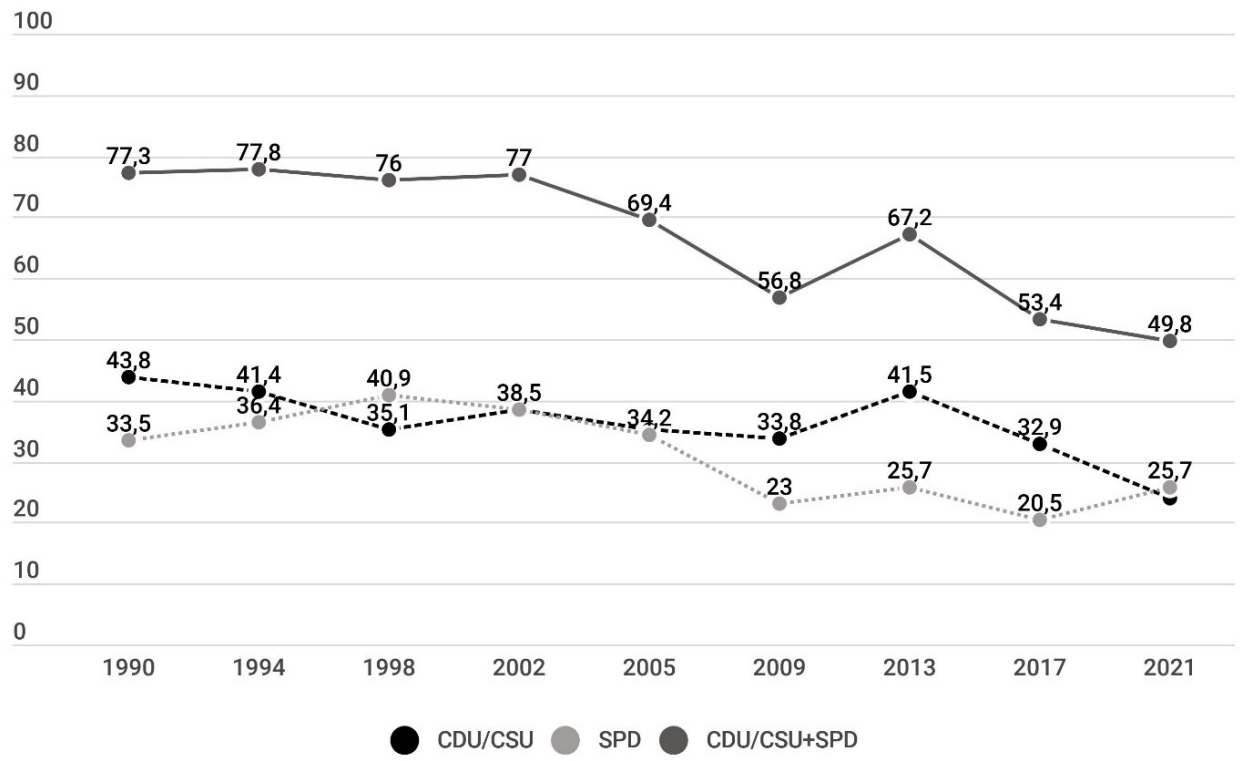

Tartományi szinten az eredmények összességében hasonló képet mutatnak (Wahlrecht, 2021b), valamint regionális megosztottság is megfigyelhető. A néppártok szavazói támogatottsága azonban - Tüiringiát kivéve - továbbra is minden tartományban meghaladja a többi pártét, regionális különbségek leginkább a néppártok közötti megosz lásában tapasztalhatóak (Election.de, 2021).

A regionális megosztottság a kelet-nyugat törésvonal mentén is megmutatkozik. Az új tartományok - Brandenburg, MecklenburgElő-Pomeránia, Szászország, Szász-Anhalt és Türingia - szavazói támogatottságra vonatkozó adatsorai leginkább éppen a CDU/CSU és 3 Forrás: Statista, 202la. 


\section{Külïgyi Szemle}

az SPD tekintetében térnek el a nyugati tartományokban mért ered ményektől. Míg nyugaton jellemzően a Német Szabaddemokrata Párt (Freie Demokralische Parlei, FDP) és a Zöldek (Die Grünen), az új tartományokban az FDP mellett 2007-ig a Demokratikus Szocializmus Pártja (Partei des Demokratischen Sozialismus, PDS), majd azt követően a Baloldali Párt (Die Linke), illetve 2017 óta az Alternatíva Németországért (Alternative für Deulschland, AfD) követi a néppártokat (Election.de, 2021). A politikai attitűdökben a német pártrendszeren belül 1990-től nagyjából 2015-ig a nyugati és a keleti tartományok között folyamatos konvergencia volt megfigyelhető, ez a trend azonban 2015 körül megfordult, és enyhe divergencia vált jellemzővé, ami a már említett pártpreferenciák változásán is tetten érhető (Holtmann, 2020).

\section{A néppártok tagsága és a korcsoportokon belüli preferenciák}

A néppártok helyzetét a tagságuk alakulása is befolyásolja. Egyrészt annak összetétele (hiszen a néppártfogalom kritériumrendszerének egyik fontos eleme a minél szélesebb társadalmi rétegek megszólítása), másrészt a tagok száma, mert ez utóbbi változása párhuzamba állítható a választási eredmények gyengülő - ám a más pártokkal való összevetésben továbbra is kiemelkedően magas - tendenciájával.

Az elmúlt évtizedekben a néppártok tagjainak száma merede ken zuhanni kezdett: a CDU és az SPD esetében 1990 és 2019 között csaknem a felére esett vissza (ld. 2. ábra). Habár ez a folyamatosan csökkenő tendencia szembetûnő, a néppártok tagjainak száma jelenleg is többszöröse a többi párténak. Az utóbbi időkben a Zöldek és az AfD tagságának enyhe növekedése tapasztalható, a többiek esetében minimális csökkenésról beszélhetünk, azonban a néppártokéhoz hasonló mértékű visszaesés egyik pártnál sem mutatkozik (Statista, 2021b). 


\section{2. ábra ${ }^{4}$}

A CDU-, a CSU- és az SPD-tagok számának alakulása 1990-2021 között

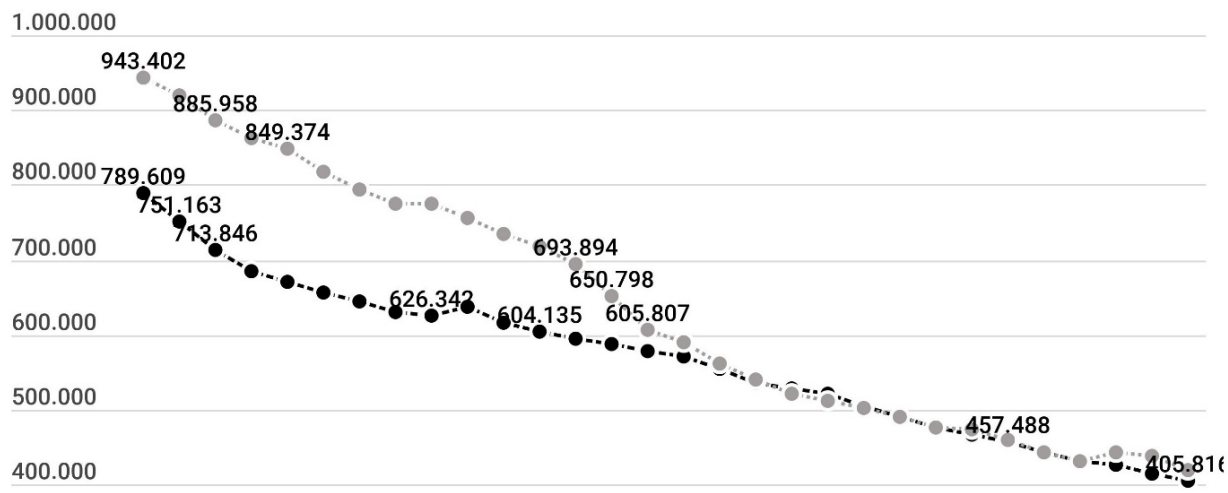

300.000

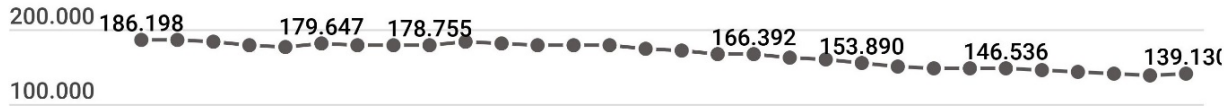

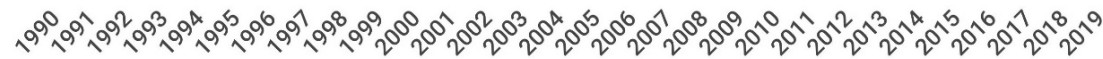

CDU CSU SPD

A néppártok tagjainak száma összességében tartományi szinten is csökkenő tendenciát mutat, bár az egyes pártok rekrutációs képességében jelentős regionális különbségek figyelhetők meg. A CDU tagjainak száma minden tartományban csökkent; a visszaesés Szász országban a legnagyobb, míg Berlinben a legkisebb mértékủ. Az SPD tagsága Türingiában és Brandenburgban nött ugyan, a többi tartományban azonban csökkent - a legtöbbet Brémában. A nyugat-keleti különbségek jól kimutathatóak: az új tartományokban a CDU tagsága 72,7, az SPD-é pedig 6,1 százalékkal csökkent, míg a nyugati országrészben a szociáldemokraták taglétszáma ennél jóval nagyobb mér tékben, 56,8 százalékkal esett vissza, a kereszténydemokratáknál ez a visszaesés 43,7 százalékos volt (Niedermayer, 2020a, 21. o.).

4 Forrás: Statista, 2021b. 


\section{Külïgyi Szemle}

A tagságok összetételében is jelentős változások figyelhetők meg. A 60 évnél idősebbek aránya mindkét pártban jelentősen megnőtt: a CDU-ban 29,7-ról 52,4, az SPD-ben pedig 25,2-ről 56,4 százalékra. Az alapfokú végzettséggel rendelkező, illetve az iskolai végzettséggel nem rendelkező tagok mindkét pártban alulreprezentáltak: arányuk a CDU tagjainak sorában 20, az SPD tagságában 23 százalék. A közép és felsőfokú végzettségủek aránya jelentősen nagyobb a néppártokban, mint a teljes lakosságon belül: a CDU tagságában 43, az SPD ében pedig 41 százalék (Niedermayer, 2020b).

A demográfiai adatok a választói magatartás tekintetében is hasonlóképpen alakultak. A CDU korábban a legtöbb szavazatot mindig a 60 év felettiek körében szerezte, a leggyengébb eredményt 1990ben a 25-34, az azt követő választásokon pedig a 18-24 év közöttiek körében érte el (Hirndorf, 2021, 19. o.). Az SPD esetében árnyaltabb képet látunk: a párt 1990-ben még a 25-34 év közöttiek körében volt a legnépszerúbb, majd a támogatottság 2002-re a még fiatalabb, a 18-24 éves korosztály irányába mozdult el. Ám 2005 után elveszítette a fiatalok szimpátiáját, és inkább a 60 év felettiek körében vált népszerủvé; a legtöbb szavazatot máig ebből a korcsoportból szerzi (Hirndorf, 2021, 20. o.). A 2021-es szövetségi parlamenti választáson a néppártokra a 70 év feletti korcsoportból szavaztak a legtöbben. A 18-34 év közöttiek körében a Zöldek, a 35-69 évesekében az SPD, a 70 év felettiekében pedig a CDU/CSU támogatottsága volt a legmagasabb (Statista, 2021c).

\section{A választói magatartást befolyásoló témakörök}

A néppártok választási eredményeiben és a tagság változásában mu tatkozó tendenciákat a közbeszédet aktuálisan foglalkoztató téma körök is meghatározzák. Egyrészt mert ezek a témakörök nem függetleníthetők a mindenkori kormánypártok vezetőinek döntéseitől, ami a kirchheimeri néppártmodellt alapul véve kérdéseket vet fel a karizmatikus és kompetensnek tủnỏ pártvezetés kritériumával öszszefüggésben. Másrészt, ugyanebből a feltételrendszerből kiindulva, 
amennyiben a választókat politikai fogyasztóknak tekintjük, úgy a fogyasztói döntéseikre nyilvánvalóan nagy hatást gyakorol az aktuális élethelyzetük, valamint az aggodalmaik és a várakozásaik.

A német közvéleményt foglalkoztató témakörök közül az 1990-es években elsősorban a munkanélküliség magas aránya váltott ki tár sadalmi szinten aggodalmat. A 2000-es évek elején a munkanélküliség, illetve az azzal összefüggő állami intézkedések kérdése továbbra is meghatározó maradt, valamint az iraki háború vitatott megítélése is tematizálta a közbeszédet. A kormánnyal kritikus tendenciába illeszkedik továbbá, hogy 2005-ben a gazdaság teljesítményével kapcsolatos félelem rekordmagasságot ért el a német társadalomban (InfoCenter, 2021). Mindez rendkíviul negatívan hatott az SPD válasz tói támogatására, és végüil a piros-zöld koalíció kudarcához vezetett. 2010 körül a gazdasági válság, a természeti katasztrófák és a pártok közötti nézeteltérések jelentették a közvélemény számára a legmeghatározóbb témaköröket (InfoCenter, 2021). A soron következő, 2013 as választáson a CDU/CSU könyvelhette el a legnagyobb nyereséget az előzô választáshoz képest, ami többek között az euróválsághoz kapcsolódó krízismenedzsmentnek is köszönhető volt. 2016 körüil új témakörként bukkant fel a terrorizmus, a politikai szélsőségek és a menekültek Németországba áramlása (InfoCenter, 2021). A 2017-es választáson a $\mathrm{CDU} / \mathrm{CSU}$ vesztesége volt a legnagyobb - részint a menekültválság kezelésének vitatott megítélésével összhangban. 2020 ban a koronavírus-járvány vált meghatározó témakörré, egy 2021-ben készült felmérés szerint pedig a választók szavazási döntését a kör nyezetvédelem, a szociális biztonság és a gazdaság-munka témakörei befolyásolták a legerőteljesebben (Statisıa, 202ld). A legutóbbi szövetségi parlamenti választáson ismét a $\mathrm{CDU} / \mathrm{CSU}$-nak kellett elkönyvel nie a legnagyobb szavazatcsökkenést, a legnagyobb nyereség pedig az SPD és a Zöldek eredményeiben mutatkozott. 


\section{Külïgyi Szemle}

\section{Miért hagyja el a nép a néppártokat?}

Ebben a fejezetben azokat az okokat fogjuk feltárni, amelyek a nép pártok csökkenő választói támogatottsága mögött rejlenek. Az elem zésben alapvetően a Németországon belüli politikai, szociológiai és kulturális változások figyelembevételével fogjuk megmagyarázni, hogy milyen tendenciák mutatkoznak az utóbbi több mint 30 évben a néppártok választási teljesítményei mellett az egyes pártokra vonatkozó politikai identifikáció mögött.

A néppártok mögül eltûnő nép folyamatának elemzésekor elsősorban egy megatrendet szüikséges megemlíteni, amely nemcsak Németországban és általában a nyugati világban, hanem gyakorlatilag globális szinten érzékelteti a hatását. Az 1960-as évek óta fokozódó individualizáció következtében a személyi választás szabadsága és az önrendelkezés egyre fontosabb teret kapott, és ennek során a tra dicionális társadalmi kötöttségek felszakadtak és háttérbe szorultak. Ennek az egyik kézzelfogható bizonyítéka a társadalom részvétele a küiönböző önszerveződési formákban, így politikai pártokban, érdekképviseleti csoportokban, egyletekben, szakszervezetekben, polgári kezdeményezésekben, klubokban stb. Egy kutatás szerint ugyanis Németországban látványosan nőtt a tagsággal nem rendelkezỏ lakosság létszáma: 2010 és 2018 között 56-ról 37 százalékra esett vissza azoknak az aránya, akik valamilyen társadalmi szervezetben aktív tevékenységet végeztek (Weßels, 2021). A keleti tartományokban az ott amúgy is nagyobb társadalmi passzivitás még inkább jellemző lett a kérdéses időszakban, de a nyugatiakban is csökkent a polgárok elköteleződése (2018-ban az előbbiben a lakosság 24, míg az utóbbiban a 40 százaléka volt aktív valamilyen szervezetben).

A növekvő individualizálódás, illetve azzal párhuzamosan a társa dalmi elköteleződés csökkenése a pártok aktív tagságának a létszámá ra is hatással van (ld. 2. ábra). Ráadásul - a néppártoktól való elfordulás tendenciáját katalizálva - az olyan szervezetekben való társadalmi részvétel is visszaesett, amelyek alapvetően fontos funkciót látnak el a pártkötődés kialakításában. A német baloldal, illetve konkrétan az 
SPD számára ezt a fórumot klasszikusan a szakszervezetek jelentik, a konzervatívoknak, vagyis a CDU/CSU-nak pedig leginkább az intézményesült keresztény egyházak (Eith, 2005). Ahogy a 3. ábra is mutatja, a német egység megvalósulása óta a legnagyobb dolgozói érdekképviseleti szerv, a Német Szakszervezeti Szövetség (Deulsche Gewerkschaftsbund, DGB) a tagjai felét, míg a két legjelentősebb német egyház, a katolikus és az evangélikus, az egynegyedét veszítette el.

\section{3. ábra ${ }^{5}$}

A DGB és a keresztény felekezetek (katolikus és evangélikus egyház) tagiainak száma, 1990-2019 (millió fó)

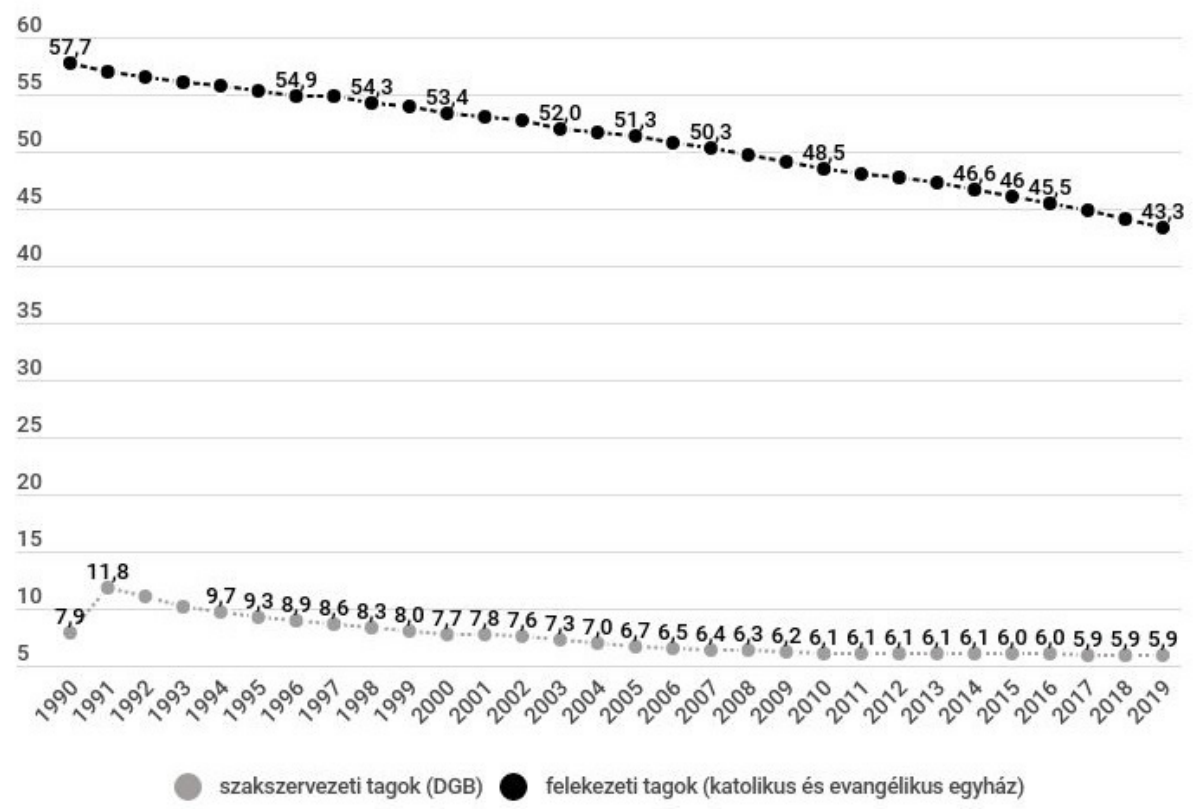

Az előbbi kapcsán érdemes szót ejteni a német társadalmi struktúra elmúlt három évtizedben bekövetkezett változásáról. Össznémet szinten 1991 és 2017 között a társadalom felső és alsó osztályának az aránya nagyjából konstans maradt, a középosztály összetételében

5 Forrás: Deutscher Gewerkschafisbund. 2021; Bundeszentrale für Politische Bildung, 2020. 


\section{Külïgyi Szemle}

azonban jelentős változás állt be: az alsó középosztály aránya közel 27,8-ről 16 százalékra csökkent, míg a felső középosztályé 19,4-ről 26,3 százalékra nőtt (Lengfeld és Ordemann, 2020). E folyamat összefügg a világgazdaság globalizálódásával, vagyis egyrészt a németországi ipari termelés visszafejlődésével és kiszervezésével, másrészt a magas hozzáadott értéket képviselő szolgáltatóipar fejlődésével. Mindez azért releváns a néppártok helyzetének fejlődése szempontjából, mert míg a felső középosztály alapvetően egy társadalmilag diverz csoport, amelynek a tagjai kisebb mértékben kötődnek pártokhoz, addig az ipari termelésben dolgozó alsó középosztályé a szakszervezeteken keresztül magasabb fokú pártkötődéssel rendelkeznek.

A pártoktól való elfordulás, ami a tagok számának csökkenésében mutatkozik meg, nemcsak - de a leglátványosabban - a CDU/CSU-t és az SPD-t érinti, hanem a Zöldeken és az AfD-n kívül a parlamentben képviselt másik két pártot is (FDP, Die Linke). A társadalom individua lizációja szempontjából ugyanakkor a néppártok létszámcsökkenésé nek van egy sajátos aspektusa, ami miatt ez a folyamat különbözik a többi párt tagságát érintő változásoktól.

A 20. század második felében zajlott nagy politikai küzdelmeket egy osztályharc határozta meg, amelyet a tőke (konzervatív) és a munka (szociáldemokrata), illetve az azok képviseletét ellátó néppártok közötti feszültség fémjelzett. A 21. század politikai nézetküilönbsége ket - az eddigi tapasztalataink alapján - sokkal inkább az identitáspo litikára alapuló kultúrharc jellemzi. A politikai konfliktusvonalak pedig ebben a dimenzióban már kevésbé a CDU/CSU és az SPD, sokkal inkább a Zöldek és az AfD között húzódnak: a nyílt-zárt társadalom, a multikulturalizmus-nacionalizmus stb. ellentétek az egymástól jól és egyértelműen megküilönböztethető két végén a zöld és a jobboldali radikális párt helyezkedik el. Mivel az individualizálódott társadalomban a társadalmi osztályokhoz való tartozás már nem játszik igazán meghatározó szerepet a politikai vitákban, ezért az identitáskérdé sekben pragmatikus, de legalábbis nem szélsőségesen az egyik vagy a másik oldal álláspontját képviselő néppártok mögüil a választók átpártoltak az egyértelmú üzeneteket megfogalmazó formációkhoz - ezek 
Németországban a Zöldek és az AfD. A nyugati társadalmak individualizációja és az identitáspolitikára alapuló kultúrharc így együtt, egymást katalizálva hat a néppártok politikai támogatottságára (Häusler, 2017; Rulff, 2019).

A német társadalom diverzebbé válásának az egyik fokmérője a tár sadalmi összetétel szerkezeti változása. Ennek egyik indikátora a né met és a küllföldi, illetve a migrációs háttérrel rendelkező állampolgárok aránya az össztársadalomban. A hivatalos terminológia különbséget tesz a küllföldi lakosság (ausländische Bevölkerung) és a migrációs háttérrel rendelkező személyek (Menschen mit Migrationshintergrund) között. Az utóbbi egy tágabb és átfogóbb kategóriát képez, s mivel Németországban szövetségi szinten először egy 2005-ös népszám lálásnál alkalmazták (Böckler és Schmitz-Veltin, 2013, 6. o.), nem áll rendelkezésre olyan összehasonlító statisztika, amely az ő számuk és társadalmi arányuk 1990 és 2021 közötti változását mutatná.

A német kormányzati statisztikák szerint az országban élő küllföldi állampolgárok aránya jelentősen megnőtt a vizsgált időszakban: míg 1990-ben a társadalom 7 százaléka számított külföldinek (5,6 millió fô), addig 2019-re 12,5 százalékra (10,4 millió fö) nôtt ez az arány (Bundesinstitut für Bevölkerung, 2021). A migrációs háttérrel rendelkező személyeknek a társadalmon belüli aránya ennél magasabb: az állami statisztikák szerint 2020-ban a lakosság 26,7 százaléka, vagyis 21,9 millió fö tartozott ebbe a kategóriába (Destatis. Statistisches Bundesamı, 2021). Az első, erre a kérdésre is kiterjedő népszámlálás kor, 2005-ben, a társadalom 18,6 százaléka (15,3 millió fő) számított migrációs hátterűnek. Leszögezhetjük tehát, hogy akármelyik statisz tikát is vesszüik figyelembe, a Németországban élő migrációs hátterű vagy küllföldi lakosok száma és az össztársadalmon belüli aránya nö vekvő tendenciát mutat (Bundesinstitut für Bevölkerung, 2021).

A jelen kutatást illetően ezek a statisztikai adatok abból a szempontból relevánsak, hogy jobban lássuk, a német társadalom nemzeti és etnikai sokszínúbbé válása milyen hatással van a pártkötődés kialakulásának a folyamatára. A DIW Berlin egy 2021-es tanulmánya szerint a teljes társadalom és a bevándorlók között lényeges különbség 


\section{Külïgyi Szemle}

van a pártkötődés megléte, illetve meg nem léte alapján: míg az előb bi 43 százalékának van valamilyen pártkötődése, addig az utóbbiak körében ez az arány 28 százalék (Jacobsen és Kroh, 2021, 494. o.). Ennek oka az, hogy a pártkötődés csak hosszú évek során fejlődik ki. A kutatás szerint ráadásul a bevándorlók szimpátiája csak lassan alakul ki egy-egy párthoz, ez általában a Németországban töltött elsô év után 8 , az ötödik után 25, a tizedik után 42, míg a huszonötödik után 58 százalékuk esetén történik meg.

Ami a konkrét pártkötődést illeti, a kutatás alapján tisztán látszik, hogy míg az 1980-as évek közepe-vége felé a migrációs háttérrel ren delkezők egyértelmú favoritja az SPD volt (53\% arányú támogatott ság; CDU/CSU: 37\%), addig a 2000-es évek közepére a két párt közti különbség eltűnt. Ezt követően a néppártok támogatottsága együtt csökkent: a 2015-2019-es időszakban mindkettőé mindössze 32 szá zalékot ért el. A vizsgált, 31 évet felölelő időszakban egyébként alap vetően a baloldali pártok esetében volt magasabb a pártidentifikáció a migrációs háttérrel rendelkező személyek körében, mint a többségi társadalomban. Ugyanakkor, míg a Zöldek támogatóinál ez a szimpátiabeli küiönbség 2015-2019-re eltűnt, addig az SPD és a Die Linke szavazói táborában továbbra is nagyobb az arányuk a migrációs hát terű személyeknek a saját csoportjukhoz mérten, mint a többieknek (Jacobsen és Kroh, 2021, 494-496. o.).

A migrációs háttérrel rendelkező személyek általában kisebb arányban élnek a demokratikus jogaikkal, és vesznek részt a parlamenti választásokon. Egy 2020-as tanulmányban közzétett felmérés szerint 65 százalékuk, míg a migrációs háttérrel nem rendelkezők 85,8 százaléka adta le a voksát a 2017-es szövetségi parlamenti választáson (Sachverständigenrat deutscher Stiftungen für Integration und Migration, 2020, 30. o.). Az alacsonyabb választási részvétel alapvetően összefüigg a gyenge pártkötődéssel, a politikai aktivitás hiánya pedig a döntéshozót gyengébb legitimációval ruházza fel a közügyek intézésében. A migrációs háttérrel rendelkező állampolgárok gyenge politikai identifikációját már korábbi tanulmányok is feldolgozták (ld. Kroh és Tucci, 2009; Wüst és Faas, 2018), és hasonló eredményekre 
jutottak, mint a DIW Berlin feljebb idézett 2021-es tanulmánya. Ezek alapján tehát kijelenthető, hogy a politikai integráció és részvétel ügye nem mozdult előre az évek során.

A szociológiai, gazdasági és kulturális folyamatok után ki kell térni a néppártok egyes politikai döntéseire is, amelyek szintén lényeges hatással voltak a tőlük való elfordulás folyamatára. Wolfgang Merkel politológus a néppártok „négy képviseleti gyengeségét” különböztette meg egy 2017-es cikkében. Az első az 1970-es években kezdődött, amikor is a magas állami eladósodottságtól tartva fóként a konzer vatív, de a szociáldemokrata pártok is meghirdették a „kisebb állam” paradigmát, csökkentették a szociális kiadásokat, és nagyobb egyéni felelősségvállalást követeltek az állampolgároktól. Ennek következtében az állami transzferektől a leginkább függő, alsóbb társadalmi ré tegek, akik klasszikusan a néppártokon keresztuil tudták a legjobban érvényesíteni az érdekeiket, fokozatosan elfordultak a politikától, és az 1990-es évek óta a jobboldali populista pártok számára jelentenek könnyen megnyerhető választási csoportokat.

A második gyengeség a balközép pártoknak az a mulasztása, hogy az 1970-es évek végén nem ismerték fel idóben a növekedésorientált gazdaság és a véges erőforrással rendelkező ökológia közötti, egyre erősödő konfliktust, az így keletkező politikai teret pedig a zöld pártok töltötték be. A harmadik a szociáldemokraták történelmének hosszú árnyéka. Az 1990-es évek végén kezdődött, a munkaerőpiacot és a szociális ellátórendszereket érintő neoliberális gazdasági refor mok következtében a nagyobb állami újraelosztást követelő baloldali, posztkommunista és neomarxista pártok számára nyílt meg a politikai tér. Németországban ezt a folyamatot a Gerhard Schröder kancellársága idején meghirdetett „Agenda 2010” program fémjelezte, amelynek következtében jött létre a Die Linke. Az utolsó gyengeség az a folyamat volt, amely az 1980-as évek közepén vette kezdetét, a 2000-es években felerősödött, majd a 2015-ös menekült- és migrációs válságban éleződött ki. A keresztény-konzervatív pártok a kisebbségi jogok, a multikulturalizmus, a menekültek és a bevándorlás témájában a kozmopolita közép számára adekvát pozíciót foglaltak el, 


\section{Külïgyi Szemle}

ezzel azonban feladták a kulturálisan konzervatív ideológiai magjuk egy részét, s ezzel utat engedtek a jobboldali populisták térnyerésének (Merkel, 2017).

Az utóbbi két képviseleti gyengeséget más tanulmányok is kieme lik az elmúlt harminc év történései közül (ld. Jesse, 2021), érdekes ugyanakkor megfigyelni, hogy a két néppártnak a kormányozásuk ide jén hozott különböző döntései - az SPD részéről az Agenda 2010, illetve a $\mathrm{CDU} / \mathrm{CSU}$-nak a menekült- és migrációs válság kezelése milyen hatással voltak az adott pártok belpolitikai helyzetére. Azok következtében ugyanis mindkettőjüik választási eredményei látványosan csökkentek (ld. 1. ábra); ám míg az SPD esetében az Agenda 2010 felerősítette a pártból történő kilépési hullámot, addig a CDU/CSUnál a menekült- és migrációs válságnak ilyen katalizáló hatása nem volt (ld. 2. ábra). A két kiragadott példa egyébként alátámasztja Peter Löschének a néppárt konceptualizálásáról szóló fejezetben említett tézisét, amely szerint a néppártnak megmarad egy ideológiai támo gatói magja, akik körében magas a pártkötődés foka. Látható ugyanis, hogy végső soron a pártok ideológiai magját is kikezdő döntésekért a választók megbüntették az egyes néppártokat.

A felsorolt folyamatok összességének hatásaként Németországban ma rekordméreteket ér el az ún. váltószavazók aránya. A KonradAdenauer-Stiftung egy 2021-es tanulmánya szerint az egyes pártokat támogató szavazók esetében még ma is megfigyelhetô egy bizonyos fokú táborképződés, így a konzervatív-liberális vagy a szociáldemokrata-zöld párosok egymás irányába erős átjárhatóságot mutatnak, ugyanakkor a német politika az utóbbi 10-15 évben jelentős mértékben nyitottá vált. A választók háromnegyede (az AfD-ét leszámítva) alapvetően potenciális váltószavazónak számít, akik el tudják képzelni, hogy bizonyos esetekben az elsődleges preferenciális pártjuk helyett egy másikra adják le a szavazatukat. Az AfD tábora jóval zártabb: 45 százaléka nem tud olyan alternatívát, ahova szívesen sza vazna (Neu és Pokorny, 2021, 53. o.). 


\section{Nyugat-európai kitekintés}

A néppártok helyzete nyugat-európai összehasonlításban is hasonló képet mutat. A német néppártok kapcsán felvázolt tendencia általános jellege Ausztria, Franciaország és Hollandia példáján keresztuil érzékelhető a legszembetűnőbben. Ausztria és Németország között számos párhuzam mutatkozik a pártrendszer felépitése, a demokráciatörténeti tapasztalatok és a szövetségi állami berendezkedés tekintetében. Franciaország esetében ugyanez nem mondható el, ugyanakkor ott is megfigyelhető a korábban meghatározó irányzatok, a konzervatív és szociáldemokrata pártok pozíciójának a változása. Hollandiában szintén hasonló kép rajzolódik ki a kereszténydemokrata és a szociáldemokrata pártok tekintetében, annak ellenére, hogy a holland és a német politikai és közjogi rendszer tradicionálisan eltér egymástól.

Az elmúlt időszakban Németországhoz hasonlóan Ausztriában is csökkent a szociáldemokraták, azaz Ausztria Szociáldemokrata Pártja (Sozialdemokratische Partei Österreichs, SPÖ) és a kereszténydemokrata Osztrák Néppárt (Österreichische Volkspartei, ÖVP) szavazói támogatása (Statisıa, 202le) és taglétszáma (Statisıa, 2019). További probléma a két párt szemszögéból, hogy a lakossággal való intézményi kapcsolatuk megcsappant: az ÖVP egyre szűkebb társadalmi rétegek érdekeit képes maradéktalanul képviselni, az SPÖ klasszikus szavazói bázisából pedig egyre többen voksolnak a nemzeti konzervatív Osztrák Szabadságpártra (Freiheitliche Partei Österreichs, FPÖ). Ezekre a problémákra egyelőre egyik párt sem reagált szervezeti szinten, ráadásul a néppárt státusz fenntartásához szüikséges országos szintủ aktív jelenlét terén is mindkét pártnál hiányosságok mutatkoznak (Moser, 2013, 188. о.).

Franciaországban a nagy pártok számára a 2000-ben elfogadott alkotmányreform óta a politikai rendszer egyre erôteljesebb prezidencializálódása, valamint a pártokon belüli pluralizmus problémája jelenti a legnagyobb kihívást. A francia pártrendszert alapvetően két formáció, a liberális-konzervatív A Republikánusok 


\section{Külïgyi Szemle}

(Les Républicains, LR) és a szociáldemokrata Szocialista Párt (Parti socialisle, PS) alakítja, esetükben azonban nem beszélhetünk a hagyo mányos értelemben vett néppártokról (Eisermann, 2013, 198. o.). A két párt pozíciójában 2017-ben mutatkozott első ízben nagyobb törés, amikor egyiknek a jelöltje sem tudott bejutni az elnökválasztás második fordulójába, azóta pedig az is egyértelmủvé vált, hogy a két párt az ellenzéki megújuláshoz füzött reményeket sem tudja beteljesíteni (Wiegel, 2021). A némettől eltérően, a francia pártrendszer rendkívül rugalmas: az egyes pártok perszonalizálódása következtében gyakori jelenség újak alapítása, illetve a nevük megváltoztatása.

Az 1990-es évek óta Hollandiában is csökkent a Kereszténydemokrata Tömörülés (Christen-Democratisch Appèl, CDA) és a szociálde mokrata Munkáspárt (Partij van de Arbeid, PvdA) támogatottsága, és a legutóbbi két választáson mindkét párt rendkívüil gyenge eredményt ért el (Nordsieck, 2021). A két párt válsága - a német néppártokhoz hasonlóan - a tagok számának a jelentős csökkenésével és a politikai rendszerben betöltött szerepük megváltozásával is együtt jár (Wilp, 2013, 215. o.). Fontos azonban megjegyezni, hogy az eltérő történelmi tapasztalatok, politikai kultúra és választójogi szabályozások miatt a német és a holland pártrendszer között számos különbség tapasztalható, illetve Hollandia esetében nem beszélhetünk a német értelemben vett néppártokról sem. A legszembetűnőbb eltérés a két ország politikai és közjogi rendszere tekintetében, hogy a holland választásokon a rendkívül alacsony küszöbnek köszönhetően hagyományosan jóval több párt jut be a parlamentbe, mint Németországban (Wilp, 2013, 215. o.). A német pártrendszerrel való összevetésben mutatkozó számos eltérés ellenére az említett példák összességében jól mutatják, hogy a Németországban kirajzolódó tendencia nem egyedülálló. Nyugat-Európában a nagy pártok az elmúlt évtizedek során elveszítették az addigi stabil pozíciójukat, ami a pártrendszerben betöltött hagyományos szerepük megváltozását hozta magával. 


\section{A néppártok jövơjére vonatkozó kilátások}

\section{A CDU/CSU és az SPD helyzele}

A néppártok jövőjével kapcsolatban felmerüilhet a kérdés, hogy a jelenlegi minőségüikben képesek lesznek-e hosszú távon széles társadalmi rétegek számára vonzó kínálatot felmutatni. A CDU/CSU és az SPD kilátásai ezzel összefüiggésben nagymértékben füiggenek attól, hogy mennyire tudják majd betölteni néppárti jellegüikből fakadó mindenkori szerepüket a német pártrendszerben. E tekintetben számos hiányosságuk figyelhető meg, ugyanakkor az erősségeik is nyilvánvalóak - mind a többi német párttal, mind más nyugat-európai néppárt helyzetével összevetve (Zolleis, 2013, 20. o.). Az előző három szövetségi parlamenti választás eredményeit figyelembe véve a $\mathrm{CDU} / \mathrm{CSU}$ és az SPD kapcsán is feltehető a kérdés, hogy a választói támogatás alapján egyáltalán még néppártnak tekinthetők-e, hiszen a szakirodalomban a néppárt kritériumaként szokásosan elismert, tartósan legalább 25 35 százalékos eredményt egyre kevésbé képesek teljesíteni. A többi kritérium szerint alapvetően továbbra is néppártnak számítanak, de e státuszuk a várható jövőbeli tendenciák tükrében veszélyeztetettnek minósíthető. Hosszú távon a CDU/CSU helyzete valamivel jobb, mint az SPD-é (Hirscher, 2013, 40. o.), a trend azonban mindkettőjük esetében hasonló. A választói támogatás visszaesése ellenére a néppártok továbbra is fix pontoknak tekinthetők saját szavazótáboruk számára, ugyanakkor a választói magatartás volatilitása miatt nem zárható ki a jövőbeli támogatottságuk további csökkenése.

\section{Afeltörekvó Zöldek - új néppárt a láthatáron?}

A közvélemény egyre erősödő környezettudatossága, valamint az, hogy a Zöldek napirendje a politikai közép szavazói számára hitelesebbé vált, az elmúlt években a párt választói támogatásának jelentős növekedését eredményezte. A 2021-es szövetségi parlamenti választáson a Zöldek a történetének legjobb választási eredményét érte el. 


\section{Külïgyi Szemle}

A néppártok jövőbeli kilátásai szempontjából ez azért releváns, mert a Zöldek hosszabb távon komoly kihívást jelenthetnek számukra. Nem csak azért, mert a párt a modern kommunikáció révén mind több váltószavazó szimpátiáját nyeri el, hanem azért is, mert egyre inkább minőségi hasonlóságot mutat a néppártokkal. Az említett kritériumok alapján azonban kijelenthető, hogy a Zöldek az egyre nagyobb mértékủ támogatás ellenére sem tekinthetô néppártnak.

A tartós választási eredmények tekintetében a párt támogatott sága messze elmarad a 25-35 százalékos minimumtól: a legnagyobb szavazati arány, amit szövetségi parlamenti választáson el tudott érni, 14,8 százalék (Wahlrecht, 2021a). Tagjainak száma ugyan 1990 és 2019 között több mint a duplájára, 41.317-ről 96.487 főre nôtt, és a Zöldek jelenleg a harmadik legnagyobb tagsággal rendelkező párt a CDU/CSU és az SPD után, ez a szám nagyságrendileg meg sem közelíti a két néppárt taglétszámait, melyeknek körülbelül a negyedét teszi ki (Statista, 2021b). A párt a társadalmi heterogenitás kritériumát sem teljesíti: a választói jelenleg nem képviselik ahhoz a társadalmi csoportok kellően széles körét. A Zöldek szavazótábora az utóbbi időben elsősorban a fiatal, magasan képzett, női választók irányába mutat erős elmozdulást (Mühlberger, Boettcher és Walther, 2021, 2. o.). A növekvő választási sikerei és a tagok száma ellenére tehát a Zöldek nem felel meg maradéktalanul a szakirodalomban bevett kritériumoknak, jelenleg nem tekinthetô néppártnak.

\section{Átalakuló német pártrendszer}

A néppártok támogatottságának csökkenésével Németországban is a Hollandiában látható politikai helyzet van kialakulóban: a pártpolitikát lassanként nem két nagy tömb és az azok körüli kisebb csoportosulások, hanem 5-6, 10-20 százalékos támogatottságú párt versengése határozza meg. A politikai rendszer ily módon történő elaprózódása, „hollandizálódása” számos új dinamikát és kihívást jelent az országos politikai életet meghatározó pártok, kiváltképp a státuszveszteséget elkönyvelni kényszerülő néppártok számára. 
Ez a folyamat ugyanakkor - paradox módon - oda vezet, hogy a néppártok egyre több tartományi kormányban képviseltetik magukat. Az országban 2021 decemberében a tizenhat tartomány mindegyikében más kombinációjú kormány volt hivatalban, amelyek közül a CDU/ CSU összesen hatban, az SPD pedig ötben nem vesz részt. Mivel a néppártok választási eredményei az elmúlt három évtizedben mindenhol csökkentek, és politikai szempontból egyelőre országos szinten az AfD-vel, a legtöbb nyugati tartományban pedig a Die Linkével való együittmúködésben kizárt a kormányalakítás, ezért ahhoz egyre gyakrabban szükség van a két néppárt koalíciójára, ami a német politikai térképet soha nem látott módon színessé teszi.

A közös kormányzati munka és az annak során szüikségessé váló kompromisszumok ugyanakkor végső soron a kezdeti probléma felerősítéséhez vezetnek: nevezetesen, hogy a néppártok kontúrjai egybemosódnak, a választók pedig egyre kevésbé tudnak különbséget tenni a pártok pozíciói között (ld. Dorn, Gäbler, Kauder, Krause, Lorenz, Potrafke és Van Roessel, 2017). Ezen a ponton érdemes visszacsatolni Otto Kirchheimer tanulmányára, amely szerint a néppártok éppen a választói támogatás maximalizálása, újabb és újabb rétegek megszólítása érdekében áldozzák fel bizonyos ideológiai pozícióikat. Az a folyamat tehát, hogy a néppártok a politika professzionalizálódása és a saját, egyre erőteljesebb technokratikus jellegük következtében hasonló pozíciót vesznek fel, valójában a politikai rendszer szüikséges velejárója, amit annak jellegéből adódóan nem lehetne hibaként a néppártok szemére vetni. A német politika elmúlt harmincéves fejlődése ugyanakkor ennek az ellenkezőjét mutatja: a néppártok közös kormányzásai, a mindinkább hasonlóvá váló pártpolitikai pozícióik, a nagykoalícióik hosszú távon éppenséggel a támogatottságuk csökkenéséhez vezettek.

A német pártrendszer helyzetét vizsgálva felmerïl a kérdés, hogy a jelenlegi tendencia a néppártok végét, valamint a német pártrendszer fragmentálódását jelenti-e. Ez azért lényeges, mert a néppártok jövőjére vonatkozóan két opció rajzolódik ki. Az egyik lehetőség, hogy a választói magatartás - a jelenlegi tendenciákat követve - oly mértékben 


\section{Külïgyi Szemle}

megváltozik a jövőben, hogy egyik párt sem lesz képes megfelelni a néppárt kritériumainak, és ezzel a néppárt mint jelenség szűnik meg Németországban, és a helyét egy több kispárt alkotta, elaprózódott pártrendszer veszi át. A másik, valószínúbb eshetőség, hogy a CDU/ CSU és az SPD hosszú távon is megtartja jelenlegi pozícióját, de a po litikai rendszerben bekövetkező változások a néppártiság újfajta kritériumrendszerét hívják életre, amely változást fog hozni a néppártok minőségét illetően.

Az utóbbit támasztja alá, hogy a CDU/CSU és az SPD esetében is megfigyelhető a néppárti státusz megtartásáért vívott küzdelem, miközben a kisebb pártok szavazói táborának a növekedését is tapasztaljuk. Náluk azonban nem mutatkozik olyan mértékủ választói pártkötődés, mint a néppártok esetében, illetve a széles körű és stabil társadalmi bázis is hiányzik. A pártrendszer fragmentálódása ellen szól továbbá, hogy a néppártokat érô veszteségekből a Zöldek kivételével egyik párt sem profitál jelentősebb mértékben. Kétségtelen azonban, hogy a CDU/CSU-t és az SPD-t a pártrendszer változásával összefüggésben az elmúlt időszakban számos veszteség érte, amelyek kapcsán a néppártok erodálódásáról beszélhetünk (Lösche, 2009). A felvázolt trendek alapján viszont nem valószínú, hogy a néppártok a jövőben teljes mértékben eltûnnének vagy feltöredeznének a német pártrendszerben, napjainkban sokkal inkább az átalakulásuknak, egy új típusú néppárt születésének képe rajzolódik ki.

\section{Konklúzió}

A CDU/CSU és az SPD politikai befolyása és társadalmon belüli tá mogatottsága az 1990 óta eltelt időszakban jelentősen visszaesett. Habár a német néppártok politikai súlya már az 1980-as évektól fokozatosan csökkenő tendenciát mutat, az számottevően felgyorsult az ezredfordulót követő évtizedekben. A befolyásuk megesappanása mögött számos tényező áll. Ezek közé lehet sorolni a közpolitikai folyamatokat illetô részvétel iránt általánosan fogyatkozó társadalmi érdeklődést, a tagok kilépéséből következően a néppártok beszûküilő 
emberi erőforrásait, a kormányzó pártok bizonyos, a párt identitás magját kikezdő specifikus politikai döntéseit (Agenda 2010, mene kült- és migrációs válság), továbbá a német társadalom diverzifikációja miatt a politika iránt megjelenő, általánosan eltérő állampolgári igényeket (individualizálódás).

A német politika jelentős mértékben „hollandizálódott” az utóbbi években: ma a tartományi kormányok korábban soha nem látott színskáláját képezik le a politikai palettának. Ám az eltérő koalíciós kons tellációk mindegyikében az egyik vagy a másik, de némely esetben mindkét néppárt képviselteti magát. Szövetségi szinten pedig még egyetlen egy alkalommal sem fordult elô 1949 óta, hogy ne valamelyikük adta volna a kancellárt.

Amennyiben a Németországban zajló politikai folyamatokat a vele szomszédos nyugat-európai államok utóbbi tízéves eseményeivel vetjük össze, akkor megállapítható, hogy ott nem fordult elö, hogy egy alulról jövő mozgalom leváltotta volna a régi rendszer két meghatározó váltópártját, mint Franciaországban, vagy egy belülről végbemenő hatalomátvétel következtében az egyik néppárt olyan mértékig átalakuljon, hogy igazából csak annak vezetője ad politikai iránymutatást, ahogy az Ausztriában történt.

A stabilitást preferáló német politikai kultúrából adódóan az eddigi tapasztalatok szerint a néppártok rendszerstabilizáló funkciója még elegendő vonzerôvel bír ahhoz, hogy ne váljanak teljes mértékben a pártrendszer nélküilözhető elemeivé. A felsorolt érvek tükrében a jelen tudásunk alapján ki lehet jelenteni, hogy Németországban a CDU/CSU és az SPD politikai szerepe az utóbbi több mint 30 évben jelentős mértékben erodálódott ugyan, de a német néppártok csillaga egyelőre (még) nem áldozott le.

\section{Irodalomjegyzék}

Böckler, Stefan és Schmitz-Veltin, Ansgar (szerk.) (2013). Migrationshintergrund in der Statislik-Definitionen, Erfassung und Vergleichbarkeit. Köln: Verband Deutscher Städtestatistiker - VDSt. 


\section{Külïgyi Szemle}

Bundesinstilut für Bevölkerung (2021). Ausländische Bevölkerung (1970 2019). A letöltés ideje: 2021. december 9. https://www.bib.bund.de/DE/ Fakten/Fakt/B39-Auslaendische-Bevoelkerung-ab-1970.html.

Bundeszentrale für Politische Bildung (2020). Katholische und evangelische Kirche. A letöltés ideje: 2021. december 9. https:// www.bpb.de/nachschlagen/zahlen-und-fakten/soziale-situation-indeutschland $/ 61565 /$ kirche.

Carstens, Peter (2011). Düstere Zeiten für Union und SPD. Deulschland Funk. A letöltés ideje: 2021. december 9. https://www.deutschlandfunk. de/duestere-zeiten-fuer-union-und-spd-100.html.

Destalis. Slatislisches Bundesaml (2021). Bundestagswahl 2021: Jede dritte Person mit Migrationshintergrund war wahlberechtigt. A letöltés ideje: 2021. december 9. https:/www.destatis.de/DE/Presse/ Pressemitteilungen/2021/10/PD21_463 125.html:jsessionid=E8B63BB BEE3733DA850DDDE1E5BCF5FA.live742.

Deulscher Gewerkschafisbund (2021). Die Mitglieder der DGB

Gewerkschaften. A letöltés ideje: 2021. december 9. https:/www.dgb. de/uber-uns/dgb-heute/mitgliederzahlen.

Doemens, Karl (2014). AfD mit Mitgliedsplus. Frankfurter Rundschau. A letöltés ideje: 2021. december 9. https://www.fr.de/politik/ mitgliedsplus-11168062.html.

Dorn, Florian, Gäbler, Stefanie, Kauder, Björn, Krause, Manuela, Lorenz, Luisa, Potrafke, Niklas és van Roessel, Alexander (2017). Demokratische Vielfalt in Deutschland - unterscheiden sich die Volksparteien noch? ifo Schnelldienst, $70(20), 28-37$.

Eisermann, Daniel (2013). Zur Lage der großen französischen Parteien „Präsidentialisierung” undinnerparteilicherPluralismus. In RalfThomas Baus (szerk.), Parleiensystem im Wandel-Perspekliven, Strategien und Polenziale der Volksparleien (197-211. o.) A letöltés ideje: 2021. november 27. https://www.kas.de/c/document_librarv/get_file?uuid=52c3cb53925e-50d3-430e-bbf094ce9524\&groupId=252038.

Eith, Ulrich (2005). Parleibindungen in Deulschland. Einstellungsprofile, Wahlrelevanz, politische Handlungsmöglichkeiten. Sankt Augustin: Konrad-Adenauer-Stiftung.

Election.de (2021). Bundestagswahl 2021 - Zweitstimmen und Sitze in den Bundesländern. A letöltés ideje: 2021. november 13. https://www. election.de/cgi-bin/tab.pl?datafile=btw21l.txt. 
Giebler, Heiko, Lacewell, Onawa P., Regel, Seven és Werner, Annika (2013). Mythos „Volkspartei”: Was niemals war, kann kaum verschwinden. WZB-Milleilungen, $13917-21$.

Häusler, Alexander (2017). Die Grünen als eigentlicher Gegner der AfD. Heinrich-Böll-Sliftung. A letöltés ideje: 2022.január 11. https:/www.boell. de/de/2017/03/21/die-gruenen-sind-die-eigentlichen-gegner-der-afd.

Hirndorf, Dominik (2021). Wahlbeteiligung und Wahlverhalten nach Alter und Geschlecht in Deutschland. Konrad-Adenauer Sliftung. A letöltés ideje: 2021. november 13. https://www.kas.de/ documents/252038/11055681/Wahlbeteiligung + und + Wahlverhalten $+\mathrm{n}$ ach + Alter ${ }^{+}$und + Geschlecht + in + Deutschland.pdf/4c2323f8-dlaO-e2dOcab9-91f3159699ed?version=1.0\&t=1613568331926.

Hirscher, Gerhard (2013). Perspektiven der Volkspartei - Anmerkungen zur Wählerschaft von CDU und CSU. In Ralf Thomas Baus (szerk.), Parleiensystem im Wandel - Perspektiven, Strategien und Polenziale der Volksparleien (29-43. o.) A letöltés ideje: 2021. november 26. https:// www.kas.de/c/document_library/get_file?uuid =52c3cb53-925e-50d3$430 \mathrm{e}-$ bbfO94ce9524\&groupld=252038.

Holtmann, Everhard (2020). Entwicklung und Wandel des Parteiensystems. Bundeszentrale für politische Bildung. A letöltés ideje: 2021. november 21. https://www.bpb.de/geschichte/deutsche-einheit/langewege-der-deutschen-einheit/308110/entwicklung-und-wandel-desparteiensystems.

InfoCenter (2021). Die Ängste der Deutschen. R+V Versicherung. $R+V$. A letöltés ideje: 2021. november 27. https://www.ruv.de/ dam/jer:193d1178-b6be-422b-83f3-77026c68ea45/ruv-grafikenlangzeitarchiv.pdf.

Jacobsen, Jannes és Kroh, Martin (2021). Eingewanderte bauen nur schrittweise Bindungen an Parteien in Deutschland auf. Wochenbericht des DIW Berlin, 28, 492-499. A letöltés ideje: 2022. január 23. https://oi. org/10.18723/diw_wb:2021-28-1.

Jesse, Eckhardt (2021). Krise (und Ende?) der Volksparteien. Aus Politik und Zeilgeschichle, 71(26-27), 39-46.

Käppner, Joachim (2019). Die verwischten Identitäten der Volksparteien. Süddentsche Zeitung. A letöltés ideje: 2021. december 9. https://www. sueddeutsche.de/politik/volksparteien-krise-cdu-csu-afd-gruene1.4663979? reduced=true.

Kirchheimer, Otto (1965). Der Wandel des westeuropäischen Partei systems. Politische Vierleljahresschrifi, 6(1), 20-41. 


\section{Külïgyi Szemle}

Kroh, Martin és Tucci, Ingrid (2009). Parteibindungen von Migranten: Parteien brauchen erleichterte Einbürgerung nicht zu fürchten. Wochenbericht des DIW Berlin, (47), 821-827.

Krouwel, André (2006). Party Models. In Richard S. Katz és William J. Crotty (szerk.), The Handbook of Parly Politics (249-269. o.)

Lengfeld, Holger és Ordemann, Jessica (2020). Soziale Schichtung und die Entwicklung der gesellschaftlichen Mitte in Ost- und Westdeutschland nach 1990. Bundenszentrale für politische Bildung. A letöltés ideje: 2021. december 9. https:/www.bpb.de/geschichte/deutsche-einheit/langewege-der-deutschen-einheit/314255/soziale-schichtung.

Lösche, Peter (2009). Ende der Volksparteien. Aus Politik und Zeilgeschichte, 51(14), 6-12.

Mainwaring, Ben és McGraw, Sean (2018). How Catchall Parties Compete Ideologically: Beyond Party Typologies. European Journal of Political Research. A letöltés ideje: 2022. január 23. https://doi.org/10.1111/1475$\underline{6765.12307 .}$.

Merkel, Wolfgang (2017). Der Niedergang der Volksparteien. Frankfurter Allegemeine. A letöltés ideje: 2022.január 11. https://www.faz.net/aktuell/ politik/die-gegenwart/der-niedergang-der-volksparteien-15258528.htm l?printPagedArticle =true \#pageIndex 2.

Mintzel, Alf (1984). Die Volksparlei. Wiesbaden: VS Verlag für Sozialwissenschaften.

Mintzel, Alf (1989). Großparteien im Parteienstaat der Bundesrepublik. Aus Politik und Zeilgeschichte, (39), 3-14.

Moser, Christian (2013). Zukunftsfähigkeit der Volksparteien in Österreich Eine kritische Bestandsaufnahme. In Ralf Thomas Baus (szerk.), Parteiensystem im Wandel - Perspektiven, Strategien und Potenziale der Volksparleien (181-195. o.) A letöltés ideje: 2021. november 24. https:// www.kas.de/c/document librarv/get file?uuid=52c3cb53-925e-50d3430 e-bbfO94ce9524\&groupId $=252038$.

Mühlberger, Marion, Boettcher, Barbara és Walther, Ursula (2021). Was bewegt die Wähler im September - Post-Corona-Aufschwung oder Dürresommer?. In Stefan Schneider (szerk.), DeulschlandMonilor. A letöltés ideje: 2021. november 26. https:/www.dbresearch. de/PROD/RPS DE-PROD/PRODOOOOOOOOO0518207/Was bewegt_die_Wähler_im September\%3A Post-Corona-Au.pdf? undefined\&realload=0ucSR950oOXGQiwEGoZ/Z AD5NuXM vvOM8GHw9ZSLWcSYx3Ox29/bbVvPM2UHOR. 
Neu, Viola és Pokorny, Sabine (2021). Vermessung der Wählerschaft vor der Bundestagswahl 2021. Ergebnisse einer repräsentativen Umfrage zu politischen Einstellungen. Konrad-Adenauer-Sliflung. A letöltés ideje: 2022. január 23. https://www.kas.de/hu/monitor/detail/-/content/ vermessung-der-waehlerschaft-vor-der-bundestagswahl-2021.

Niedermayer, Oskar (2010). Die Erosion der Volksparteien. Zeilschrifı für Politik, 57(3), 265-277.

Niedermayer, Oskar (2020a). Parteimitglieder in Deutschland: Version 2020. Arbeilshefle aus dem Otto-Stammer-Zentrum, (31). A letöltés ideje: 2021. november 16. https://www.polsoz.fu-berlin.de/polwiss/ forschung/systeme/empsoz/team/ehemalige/Publikationen/schriften/ Arbeitshefte/P-PMIT20_Nr_31.pdf.

Niedermayer, Oskar (2020b). Die soziale Zusammensetzung der Parteimitgliederschaften. Bundeszentrale für politische Bildung. A letöltés ideje: 2021. november 21. https:/www.bpb.de/politik/ grundfragen/parteien-in-deutschland/zahlen-und-fakten/140358/ soziale-zusammensetzung.

Nordsieck, Wolfram (2021). Netherlands. Parties and Elections in Europe. A letöltés ideje: 2021. november 24. http://www.parties-and-elections. eu/netherlands.html.

Panebianco, Angelo (1988). Political Parlies: Organization and Power. Cambridge: Cambridge University Press.

Rulff, Dieter (2019). Warum Grüne und AfD die Parteien der Stunde sind. Detschlandfunk Kultur: A letöltés ideje: 2022. január 11. https:/www. deutschlandfunkkultur.de/kulturkampf-statt-klassenkampf-warumgruene-und-afd-die-100.html.

Sachverständigenrat deutscher Stiftungen für Integration und Migration (2020). Mitten im Spiel - oder nur an der Seitenlinie? Politische Partizipation und zivilgesellschaftliches Engagement von Menschen mit Migrationshintergrund in Deutschland. A letöltés ideje: 2021. december 9. https://www.svr-migration.de/wp-content/ uploads/2021/03/SVR-FB_Studie_Be-Part.pdf.

Seitz, Norbert (2008). Die Schwindsucht der Volksparteien. Deulschland Funk. A letöltés ideje: 2021. december 9. https://www.deutschlandfunk. de/die-schwindsucht-der-volksparteien-100.html. 


\section{Külïgyi Szemle}

Statista (2019). Anzahl der Mitglieder der politischen Parteien in Österreich im März 2017. A letöltés ideje: 2021. december 3. https:/de.statista. com/statistik/daten/studie/288668/umfrage/mitgliederzahlen-derpolitischen-parteien-in-oesterreich/.

Slatisla (2021a). Ergebnisse der „Volksparteien” CDU/CSU und SPD bei den Bundestagswahlen von 1990 bis 2021. A letöltés ideje: 2021. november 21. https:/de.statista.com/statistik/daten/studie/38130/ umfrage/ergebnisse-der-volksparteien-bei-den-bundestagswahlenseit-1990/.

Slatisla (2021b). Entwicklung der Mitgliederzahlen der politischen Parteien in Deutschland in den Jahren 1990 bis 2019. A letöltés ideje: 2021. november 21. https:/de.statista.com/statistik/daten/studie/1140195/ umfrage/entwicklung-der-mitgliederzahlen-der-politischen-parteienin-deutschland/.

Statisla (2021c). Wahlverhalten bei der Bundestagswahl am 26. September 2021 nach Alter. A letöltés ideje: 2021. november 21. https:/de.statista. com/statistik/daten/studie/1257097/umfrage/wahlverhalten-bei-derbundestagswahl-nach-alter/.

Statista (202ld). Welches Thema spielt für Ihre Wahlentscheidung die größte Rolle? A letöltés ideje: 2021. november 21. https://de.statista.com/ statistik/daten/studie/582873/umfrage/umfrage-Zu-den-wichtigenthemen-fuer-die-wahlentscheidung-in-berlin/.

Statista (2021e). Ergebnisse der Nationalratswahlen in Österreich von 1945 bis 2019. A letöltés ideje: 2021. december 3. https:/de.statista. com/statistik/daten/studie/274303/umfrage/endergebnis-dernationalratswahl-in-oesterreich/.

Wahlrecht (2021a). Ergebnisse der Bundestagswahlen. A letöltés ideje: 2021. november 19. https://www.wahlrecht.de/ergebnisse/bundestag.htm.

Wahlrechı (2021b). Ergebnisse der Landtagswahlen. A letöltés ideje: 2021. november 21. https://www.wahlrecht.de/ergebnisse/baden-wuerttemberg. htm.

Weßels, Bernhard (2021). Bindung an Interessengruppen und politische Parteien. Bundenszentrale für politische Bildung. A letöltés ideje: 2021. december 9. https://www.bpb.de/nachschlagen/datenreport-2021/ politische-und-gesellschaftliche-partizipation/330214/bindung-aninteressengruppen-und-politische-parteien. 
Wiegel, Michaela (2021). Frankreichs Volksparteien vor dem Ende? Frankfurler Allgemeine. A letöltés ideje: 2021. november 24. https:// www.faz.net/aktuell/politik/ausland/volksparteien-in-not-auch-infrankreich-17336908.html.

Wilp, Markus (2013). Politische Kräfteverhältnisse im Wandel Zur veränderten Position der Christ- und Sozialdemokratie im niederländischen Parteiensystem. In Ralf Thomas Baus (szerk.), Parleiensystem im Wandel - Perspekliven, Stralegien und Polenziale der Volksparleien (213-236. o.) A letöltés ideje: 2021. november 27. https:// www.kas.de/c/document library/get file?uuid $=52 \mathrm{c} 3 \mathrm{cb} 53-925 \mathrm{e}-50 \mathrm{~d} 3-$ 430e-bbfO94ce9524\&groupId=252038.

Wolinetz, Steven B. (2002). Beyond the Catch-All Party: Approaches to the Study of Parties and Party Organization in Contemporary Democracies. In Richard Gunther, José Ramón Montero és Juan J. Linz (szerk.), Political Parties: Old Concepts and New Challenges (136-165. o.) A letöltés ideje: 2022. január 23. https://doi.org/10.1093/0199246742.0 01.0001.

Wüst, Andreas, M. és Faas, Thorsten (2018). Politische Einstellungen von Menschen mit Migrationshintergrund. Friedrich-Ebert-Stiftung. A letöltés ideje: 2022. január. 23. https:/librarv.fes.de/pdf-files/ dialog/14347.pdf.

Zolleis, Udo(2013).Zur Lage der Volksparteien in Deutschland. In RalfThomas Baus (szerk.), Parleiensystem im Wandel-Perspekliven, Stralegien und Polenziale der Volksparleien (13-28. o.) A letöltés ideje: 2021. november 26. https: $/ /$ www.kas.de $/ \mathrm{c} /$ document library $/$ get file?uuid $=52 \mathrm{c} 3 \mathrm{cb} 53$ 925e-50d3-430e-bbf094ce9524\&groupld $=252038$. 